\title{
Voorbij de controverse: het Nederlandse neoliberalisme als onderwerp van onderzoek ${ }^{*}$
}

\author{
Merijn Oudenampsen \& Bram Mellink**
}

\section{Introductie}

Het begrip neoliberalisme fungeert vaak als onderwerp van verwoede polemieken in het publieke debat. Prominente Nederlandse auteurs hebben het neoliberalisme gelijkgesteld met fundamentalisme; sommigen identificeerden het zelfs als 'totalitair geloof' (Achterhuis, 2010; Van Rossem, 2011; Wöltgens, 1996). Daar recht tegenover staat het andere kamp. Volgens hen is het neoliberalisme een stropop en een boeman, een scheldwoord dat critici gebruiken als onderdeel van een intellectuele heksenjacht tegen het liberalisme (Bolkestein, 2009; Sanders, 2009; Van de Haar, 2012; Van Hees, Van Schie \& Van de Velde, 2014).

Het neoliberalisme is zeker niet de enige sociaalwetenschappelijke term met een dergelijke polemische status. Veelvoorkomende begrippen als populisme, nationalisme, socialisme en conservatisme vormden de aanleiding voor vergelijkbare langlopende onenigheid en soortgelijke aantijgingen van pejoratief gebruik. Wat echter uitzonderlijk lijkt aan het debat over neoliberalisme in Nederland is dat er zeer weinig uitvoerige conceptuele, empirische of historische studies zijn gepubliceerd over het onderwerp. Het begrip neoliberalisme komt weliswaar vaak terug in sociaalwetenschappelijk onderzoek, maar de meeste auteurs lijken de term te gebruiken zonder echt uit te wijden over wat ze er nou precies mee bedoelen (De Beus, Van Doorn \& De Rooij, 1996; Hemerijck, 1998; Touwen, 2014; Van Kersbergen, 1995; Voerman, 2011).

Dit artikel begint met een verkenning van de controverse rond het begrip neoliberalisme in zowel het internationale als het Nederlandse debat. Puttend uit een recente reeks toonaangevende historiografische publicaties schetst het de ontstaansgeschiedenis van het begrip neoliberalisme. Het stelt vervolgens - als middel om deze controverse te overstijgen - een ideeëngerichte benadering van het Nederlandse neoliberalisme voor. Na enkele voorlopige aanzetten hiertoe te hebben gegeven sluit het artikel af met een pleidooi voor verder onderzoek.

* Beide auteurs zijn onderdeel van het NWO-onderzoeksproject 'Market Makers', dat de geschiedenis van het Nederlandse neoliberalisme in kaart brengt. Alhoewel Mellinks geschreven bijdrage aan dit artikel zich beperkt tot de passages over de jaren vijftig, is het artikel in bredere zin product van gezamenlijke ideeënvorming binnen het onderzoeksproject.

** Dr. Merijn Oudenampsen is Postdoc onderzoeker aan de Universiteit van Amsterdam, Faculteit der Maatschappij- en Gedragswetenschappen, Programmagroep: Geographies of Globalizations. Dr. Bram Mellink is postdoc onderzoeker aan de Universiteit van Amsterdam, Faculteit der Geesteswetenschappen, Capaciteitsgroep Geschiedenis. 


\section{Neoliberalisme als vechtbegrip}

'Weinig ontdekkingen zijn zo irritant als degenen die de herkomst van ideeën blootleggen.' Met dit citaat van de Britse liberaal Lord Acton opent Friedrich Hayek $(1944,1)$ zijn politieke schotschrift The Road to Serfdom. Het boek, dat in de naoorlogse jaren in de gehele westerse wereld gretig aftrek vond, zou een van de klassieke teksten worden van de politieke beweging die indertijd door haar aanhangers het neoliberalisme werd genoemd.

Met het verstrijken der jaren is er echter grote onduidelijkheid ontstaan over het begrip neoliberalisme. De aanhangers van deze beweging identificeren zich sinds de jaren zestig en zeventig niet langer met de term vanwege onderlinge onenigheid. Vanaf het einde van de jaren zeventig krijgt de term zijn huidige, overwegend negatieve lading en verwordt het meer en meer tot een aanduiding van - en aanklacht tegen - de politiek-economische tijdgeest als zodanig. In andere woorden: neoliberalisme refereert vanaf dit punt niet langer aan een min of meer vastomlijnde politieke beweging of onderscheidbaar gedachtegoed, het is een alomtegenwoordig en nogal ongrijpbaar verschijnsel geworden (Boas \& Gans-Morse, 2009; Van Hees e.a., 2014).

Neoliberalisme, dat is de coup in Chili en de vrijemarktexperimenten van de zogeheten Chicago Boys in de jaren zeventig. Neoliberalisme, dat is de harde bezuinigingspolitiek van Thatcher en Reagan in de jaren tachtig. Neoliberalisme, dat is de globalisering en de Washington Consensus van het Internationaal Monetair Fonds (IMF) en de Wereldbank in de jaren negentig. Neoliberalisme, dat is de financiële deregulering en de daaropvolgende kredietcrisis in 2008, door auteurs als Joseph Stiglitz, Naomi Klein en Eric Hobsbawm beschreven als het 'Berlijnse muur moment' van het neoliberalisme (Peck, 2010, 9). Neoliberalisme, dat is de Europese en Amerikaanse crisispolitiek die daarop volgde. De term neoliberalisme bestrijkt zo een erg uitgestrekt terrein en lijkt te lijden aan een zekere begripsinflatie.

Het gevolg is een groeiend aantal interne tegenstrijdigheden. Door velen wordt het neoliberalisme gelijkgesteld met het radicaal inperken van overheidsinterventie en een terugkeer naar de nachtwakersstaat. Anderen daarentegen associëren het neoliberalisme juist met krachtig overheidsingrijpen. Zo vatte de vooraanstaande Britse politicoloog Andrew Gamble (1988) het neoliberale programma van Thatcher samen onder de noemer The Free Economy and the Strong State. Het neoliberalisme wordt vaak geassocieerd met monetarisme, het door Milton Friedman voorgestane monetaire beleid dat mikt op lage inflatie en een restrictief monetair en fiscaal beleid (King, 1987). Door anderen wordt de voorzitter van Federal Reserve, Alan Greenspan, als neoliberaal gekarakteriseerd, een man die juist bekend is komen te staan om zijn ruime en expansieve monetaire beleid (Achterhuis, 2010). Sommigen zien deregulering als typerend voor het neoliberalisme. Anderen wijzen juist op de uitvoerige regulering die nodig is om een vrije markt soepel te laten functioneren (Aalbers, 2016; Slobodian, 2018).

Wat bijdraagt aan de onduidelijkheid is het feit dat neoliberalisme als begrip relatief onbekend is in de VS. Terwijl velen in Europa en Latijns-Amerika de VS toch zien als hol van de neoliberale leeuw. Het neoliberalisme wordt dan ook vaak 
gelijkgesteld met amerikanisering en de wereldwijde convergentie naar een Amerikaanse vorm van ongetemd vrijemarktkapitalisme (Bourdieu, 1998; Harvey, 2005; Klein, 2007; Van Rossem, 2011). In de VS gebruikt men de term neoliberalisme echter nauwelijks, omdat het woord 'liberal' sinds de New Deal met linkse overheidsinterventie wordt geassocieerd. Daar spreekt men eerder van fiscal conservatism of libertarianism als het over vrijemarktdenken gaat (Nash, 2006). En hoewel het neoliberalisme bovenal ontwikkeld is als een economische politiek, komt de term neoliberalisme in de economische wetenschap nauwelijks terug. Neoliberale standpunten worden onder de noemer van monetarisme, neoklassieke economie, public choice of supply-side economics besproken (Blyth, 2002; Gamble, 1988; King, 1987).

Wat het neoliberalisme is, waar het vandaan komt en wat het traject is dat het door de decennia heen heeft afgelegd, is aldus verre van transparant. Sommigen zien de politiek van Reagan en Thatcher in de jaren tachtig als beginpunt, terwijl anderen eerder geneigd zijn naar denkers als Hayek en Mises in de jaren twintig en dertig te verwijzen (Burgin, 2012; Mirowski \& Plehwe, 2009). Ook zijn er auteurs te vinden die de protesten van 1968 als geboortegrond van het neoliberalisme opvoeren (besproken in Audier, 2012). Sommige auteurs zoeken de oorsprong zelfs bij de doe-het-zelf ethiek van de kraakbeweging in de jaren tachtig of bij de nasleep van de val van de Muur in de jaren negentig (Tromp, 2010; Van Oenen, 2009).

Naast deze onduidelijkheid over de oorsprong van het neoliberalisme is er nog het probleem dat het begrip langzamerhand meer een morele dan een analytische lading heeft gekregen. Toen paus Johannes Paulus II (1999) in een apostolische exhortatie het neoliberalisme veroordeelde, besprak hij het in de context van 'ten hemel schreiende sociale wandaden', even na 'drugshandel, witwassen van onrechtmatig verkregen geld, corruptie op ieder gebied, terrorisme, wapenwedloop, rassendiscriminatie, maatschappelijke tweedeling [en] redeloze vernietiging van de natuur':

'Veel Amerikaanse landen worden steeds meer overheerst door een systeem dat bekend staat als "neo-liberalisme"; uitgaande van een louter economische mensopvatting beschouwt dit systeem winst en marktwerking als absolute graadmeters ten koste van waardigheid en eerbiediging van individu en volk.'

Het neoliberalisme is daarmee op het eerste gezicht een nogal problematisch begrip. En deze constatering wordt niet enkel door auteurs aan de rechterzijde gemaakt. Het 'is een ellendig scheldwoord', 'onnauwkeurig en overmatig gebruikt', merkte Susan Watkins al eens op, hoofdredacteur van het vooraanstaande linkse tijdschrift New Left Review. Om daaraan toe te voegen dat er toch 'behoefte [is] aan een term die het macro-economische paradigma beschrijft dat sinds het einde van de jaren zeventig dominant is geworden' (geciteerd in Peck, 2010, 31). Vergelijkbare bezwaren zijn in Nederland te horen. 


\section{Het Nederlandse debat}

Als gevolg van de financiële crisis van 2008 is in Nederland, net als elders in de wereld, een heetgebakerd debat ontstaan over het neoliberalisme. Critici als Frank Ankersmit, Abram de Swaan, Hans Achterhuis, Maarten van Rossem en Jan Marijnissen stellen dat de kredietcrisis eveneens een neergang impliceert van de ideologische aanspraken van het neoliberalisme. Daar tegenover vinden we auteurs als Frits Bolkestein, Patrick van Schie, Martin van Hees, Edwin van de Haar en Stephan Sanders, die de relevantie van het begrip in twijfel trekken. Sanders schreef hierover in NRC:

'Er is een internationaal volkstribunaal aan de gang, niet alleen in contreien waar ze van oudsher dol zijn op volkstribunalen, maar ook, of juist in landen, die in de loop van eeuwen een rechtstatelijke traditie hebben opgebouwd. Verschillende en heel diverse aanklagers zijn sinds 2008 bezig de hoofdschuldige veroordeeld te krijgen, en de naam van die verdachte luidt: het neoliberalisme.' (Sanders, 2009)

Dit tweede kamp is van mening dat het neoliberalisme geen wetenschappelijke term is, maar een scheldwoord. Het begrip zou niet gebruikt worden door aanhangers van de zogenoemde doctrine, enkel door linkse tegenstanders (Bolkestein, 2009; Sanders, 2009; Van de Haar, 2012; Van Hees e.a., 2014). Deze opvatting is pregnant verwoord in een pamflet met de titel Neoliberalisme. Een politieke fictie, geschreven door de filosoof Martin van Hees, de politicoloog Mark van de Velde en Patrick van Schie, directeur van de Teldersstichting, het wetenschappelijke bureau van de VVD. De auteurs richten zich tot de linkse critici van het neoliberalisme:

'Het neoliberalisme bestaat uitsluitend in de fantasie van (sommige?) linkse mensen; zij gebruiken het als een scheldwoord voor alles wat zij verafschuwen. Het is het hekserijgeloof van deze tijd. Aan $u$ de keuze of $u$ anderen dan wel de samenleving aan heksenproeven wilt blijven onderwerpen, waarbij de beschuldigde het er hoe dan ook slecht van afbrengt, of dat u liever een wetenschappelijke grond voor uw overtuiging zoekt.' (Van Hees e.a., 2014, 73)

Wie de handschoen wil opnemen die de lezer hier op nogal provocatieve wijze wordt toegeworpen, komt al snel tot de ontdekking dat het wetenschappelijke onderzoek naar het neoliberalisme in Nederland nog in de kinderschoenen staat. Het omstreden karakter van de term lijkt opvallend genoeg tegelijkertijd oorzaak en gevolg te zijn van het gebrek aan wetenschappelijke studie naar het fenomeen (met belangrijke uitzonderingen als Van Apeldoorn, Drahokoupil \& Horn, 2009; Zuidhof, 2012a). Als gevolg daarvan is het neoliberalisme in Nederland voornamelijk verkend aan de hand van een aantal populariserende bijdragen die weliswaar de lovenswaardige ambitie hebben om het debat van meer diepgang te voor- 
zien, maar desalniettemin lijden aan wezenlijke tekortkomingen (Wöltgens, 1996; Marijnissen, 2009; Achterhuis, 2010; De Swaan, 2010; Van Rossem, 2011.

Zo portretteert Hans Achterhuis (2010) de Russisch-Amerikaanse auteur Ayn Rand als spilfiguur binnen de neoliberale beweging. Via haar discipel, de Federal Reserve-voorzitter Alan Greenspan, zou het neoliberalisme de financiële crisis hebben veroorzaakt. Ayn Rand wordt door onderzoekers echter als een vrij marginaal figuur gezien binnen de bredere neoliberale beweging. Belangrijker nog, het monetaire beleid van Greenspan gaat recht tegen de ideeën van Rand in, die een principieel tegenstander was van de Federal Reserve als zodanig (Zuidhof, 2012b).

De prominente conservatief-liberale filosoof Frank Ankersmit (2009) ontleent zijn definitie van neoliberalisme nota bene aan Wikipedia. Volgens hem is de doorbraak van het neoliberalisme een gevolg van de val van de Muur, zo'n tien jaar na de verkiezingsoverwinningen van Reagan en Thatcher, die normaliter als de doorbraak van deze stroming worden beschouwd. 'Na de val van de Muur in 1989 triomfeerde de hoogmoed. (...) Het leidde tot dat triomfantelijke neoliberalisme met zijn almacht voor de markt. (...) Je zag dat zowel in West als Oost het afgelopen moest zijn met de greep van de staat op de samenleving' (Ankersmit geïnterviewd in Tromp, 2010, 28).

Maarten van Rossem $(2011,10)$ ziet het neoliberalisme bovenal als een terugkeer naar klassiek-liberalisme:

'Neoliberalisme valt te beschouwen als de onverwachte revival van traditionele, liberale economische opvattingen. We noemen het neoliberalisme, omdat het zich aandiende na een decennia durende dominantie van een ander economisch paradigma, namelijk de Keynesiaanse Consensus of het Grote Economische Compromis.'

Het neoliberalisme diende zich echter al eerder aan, voor de 'keynesiaanse consensus' goed en wel een feit was. Daarbij werd de term neoliberalisme oorspronkelijk gemunt door neoliberale intellectuelen om juist een vernieuwing ten opzichte van het klassiek-liberalisme aan te duiden. Vandaar het voorvoegsel neo. Jan Marijnissen ten slotte, stelt het neoliberalisme gelijk met de overgang naar het Angelsaksische model in Nederland en de verlokkingen van the American way of life (Marijnissen, 2009, 23). Het probleem van deze gelijkstelling van neoliberalisme met amerikanisering is dat het geografische zwaartepunt van de neoliberale beweging aanvankelijk juist te vinden was op het Europese continent. Er is een prominente Europese traditie van neoliberalisme die weinig te maken heeft met amerikanisering.

Wat opvalt bij het verdedigende kamp is dat er duidelijk meer kennis over de ideeëngeschiedenis van het neoliberalisme aanwezig is. Zo verwijst Stephan Sanders (2009) naar de Duitse ordoliberaal Alexander Rüstow, die de term neoliberalisme in 1938 gemunt zou hebben. Tegelijkertijd lijken de auteurs in dit kamp meer geïnteresseerd te zijn in het weerleggen van de claims van de aanklagers dan in het oprecht verkennen van de geschiedenis van het neoliberalisme. Neem het argument van Van Hees e.a. dat het neoliberalisme een bedenksel is van tegen- 
standers. 'Er zijn wel denkers en politici die door tegenstanders tot neoliberaal worden bestempeld - wij zagen bijvoorbeeld al namen als die van Hayek en Friedman, respectievelijk Thatcher en Reagan -, maar zij zagen zichzelf niet als zodanig of wezen het epitheton "neo" uitdrukkelijk van de hand' (Van Hees e.a., 2014, 16), zo wordt er stellig beweerd. Wie wat pagina's verder bladert, krijgt echter te horen dat Friedman 'de term "neoliberalisme" gebruikte, om zijn eigen denkbeelden te duiden' (Van Hees e.a., 2014, 26). De lezer moet hier concluderen dat Friedman zijn eigen tegenstander is geweest.

Een vergelijkbare glasharde ontkenning is bij de voormalige VVD-leider Frits Bolkestein (2009) te vinden. 'Ik weet wat het liberalisme is, maar niet wat het neoliberalisme is. Sterker: ik ken geen liberaal die dat wel weet', stelde Bolkestein in een spraakmakende discussie met Frank Ankersmit op de landelijke opiniepagina's. Zo zette hij zijn tegenstander effectief weg als strijder tegen windmolens. Die stelling is echter alleszins opmerkelijk. Klaas Groenveld en Andreas Kinneging, respectievelijk voormalig directeur en medewerker van de Teldersstichting en beiden bij tijd en wijle tekstschrijvers van Frits Bolkestein, werkten midden jaren tachtig aan een lijvig rapport over liberalisme en economie, waarin een hoofdstuk gewijd is aan het neoliberalisme (Groenveld \& Kinneging, 1985). Bolkestein was in die tijd nauw betrokken bij de Teldersstichting en werkte niet veel later mee aan de publicatie Liberalisme: een speurtocht naar filosofische grondslagen (Kinneging, 1988), waarin deze ideeën verder zijn uitgewerkt.

Een genuanceerdere verdedigingslinie, terug te vinden bij Sanders, Kinneging en het pamflet van de Teldersstichting, is de stelling dat er weliswaar vroeger sprake is geweest van een zelfbenoemde neoliberale stroming die ook wel ordoliberalisme werd genoemd, maar dat deze politiek al lang niet meer bestaat en überhaupt weinig te maken heeft met wat (linkse) mensen vandaag de dag onder neoliberalisme verstaan. Dat strookt niet met de internationale literatuur, waar het ordoliberalisme als belangrijke invloed op het thatcherisme wordt gepresenteerd (Centre for Policy Studies, 1975; Gamble, 1988; Gray, 1993). Intrigerend is ook dat Bolkestein in zijn tijd als Eurocommissaris in een prominente lezing heeft gesteld dat hij 'een op ordoliberale leest geschoeid Europa' nastreeft (Bolkestein, 2001; zie ook: Dardot \& Laval, 2014). Bolkestein verbond deze 'ordoliberale leest' met een politiek van vrijhandel, liberalisering, deregulering en flexibilisering. Laat dat nu precies de beleidspraktijken zijn die vele van de critici onder neoliberalisme verstaan. $\mathrm{Zo}_{\mathrm{o}}$ is de inbreng van zowel aanklagers als verdediging weinig bevredigend.

\section{Oorsprong en betekenis van de term neoliberalisme}

Op internationaal vlak is de situatie gunstiger. Daar is inmiddels een indrukwekkend corpus aan academische literatuur te vinden over het neoliberalisme. Belangrijk is dat er in het afgelopen decennium een aantal historiografische studies is verschenen waarin op empirische wijze de ideeëngeschiedenis van het neoliberalisme wordt nagegaan aan de hand van intensieve archiefstudie (Walpen, 2004; Audier, 2012; Mirowski \& Plehwe, 2009; Peck, 2010; Burgin, 2012; 
Stedman, 2012). Oncontroversieel aanvangspunt van de analyse in deze literatuur is dat de term 'neoliberalisme' gezamenlijk gemunt werd door een groep intellectuelen ten tijde van het zogenaamde Walter Lippmann Colloquium in Parijs in 1938. De economische crisis in de jaren dertig en de daaropvolgende opkomst van het keynesianisme betekende een gevoelige slag voor het klassiekliberalisme en met name de laisser-fairedoctrine. Overal in de westerse wereld was sprake van een toename van overheidsinterventie en planning in de economie.

Een boek uit 1937 van de beroemde Amerikaanse journalist en New Deal-criticus Walter Lippmann, The Good Society, was een poging tot vernieuwing van het liberale gedachtegoed, in reactie op deze trend. Lippmann populariseerde kritieken op het socialisme en de economische planning die Ludwig von Mises en Friedrich Hayek eerder hadden ontwikkeld vanuit hun Weense standplaats. In zijn boek verwoordde Lippmann op toegankelijke wijze een serie denkbeelden die de kern zouden gaan vormen van het neoliberalisme. In het bijzonder de afwijzing van laisser-faire, het idee dat de overheid de voorwaarden dient te scheppen voor het behoorlijk functioneren van de vrije markt, en het strategische gebruik van de binaire oppositie tussen economische planning als collectivisme - waarbij Franklin D. Roosevelts New Deal op één lijn werd gesteld met het stalinisme en nazisme - en de gelijkstelling van de vrijemarkteconomie met politieke vrijheid. Lippmann kreeg vervolgens een uitnodiging van de Franse filosoof Louis Rougier. Deze bracht een selecte groep vooraanstaande liberale intellectuelen en zakenmensen bij elkaar voor een bijeenkomst in 1938, waar het gebruik van de term neoliberalisme expliciet werd besproken. In een stemming besloot een kleine meerderheid het woord als aanduiding van het gezamenlijke politieke project te gebruiken. Daaronder verstond men een politiek die de prioriteit van het prijsmechanisme van de markt nastreefde, evenals vrijheid van onderneming, het systeem van competitie, en een sterke en neutrale staat (Walpen, 2004, 60; Mirowski \& Plehwe, 2009, 14). Het uitbreken van de Tweede Wereldoorlog bemoeilijkte echter het opzetten van een gezamenlijk project.

Het voert te ver om dit colloquium als de geboortegrond van het neoliberalisme aan te wijzen. Zoals Mirowski en Plehwe schrijven: 'Metaphors of "birth" are perhaps less apposite here than alternative metaphors of percolation and recombination' (Mirowski \& Plehwe, 2009, 14). Veel van de aanwezigen op het colloquium waren afkomstig uit intellectuele stromingen die zich vanaf de jaren twintig al bezighielden met het formuleren van een nieuwe liberale leer. Zoals Milton Friedman in 1952 terecht zou opmerken is 'de doctrine, welke veelal het neoliberalisme wordt genoemd, (...) min of meer tegelijkertijd in verscheidene delen van de wereld ontwikkeld' (Friedman, 1952, 6). Belangrijker dan het vaststellen van de precieze geboorteplaats van het neoliberalisme is echter de vaststelling dat het neoliberalisme ontstond tijdens de economische crisis van de jaren dertig, als een reactie op de daaruit voortkomende stagnatie van het klassieke liberalisme enerzijds en de opkomst van het keynesianisme anderzijds.

Vrij direct na de oorlog, in 1947, werd een volgende stap gezet. Op initiatief van Friedrich Hayek en de zakenman Albert Hunold kwamen van 1 tot 10 april 1947 een kleine veertig deelnemers bijeen in het dorpje Mont Pèlerin, vlak bij het meer 
van Genève, onder wie veel van de eerdere deelnemers aan het Walter Lippmann Colloquium. De belangrijkste aanwezigen waren Walter Eucken (Freiburger Schule), Milton Friedman (Chicago School), Friedrich August von Hayek (LSE), Bertrand de Jouvenel (Parijs), Frank H. Knight (Chicago School), Fritz Machlup (Oostenrijkse School), Ludwig von Mises (Oostenrijkse School), Karl R. Popper (LSE), William E. Rappard (Genève), Lionel Robbins (LSE), Wilhelm Röpke (Freiburger Schule) en George J. Stigler (Chicago School). Tijdens deze bijeenkomst werd de Mont Pèlerin Society gesticht, intellectuele kraamkamer en zenuwcentrum van het neoliberalisme.

Leden van de Mont Pèlerin Society (MPS) presenteerden zich begin jaren vijftig aan de hand van een reeks van teksten expliciet als 'de neoliberale beweging' (Hayek, 1967, 200; Walpen, 2004, 48; Nash, 2006, 35). 'Gone are the days when the few outmoded liberals walked their paths lonely, ridiculed and without response from the young', zou Hayek (1952, 730) schrijven naar aanleiding van de eerste MPS-bijeenkomsten, 'at least personal contact among the proponents of neoliberalism has been established'. Zo is er tevens een bekend artikel van Milton Friedman $(1952,6)$ met als titel 'Het neoliberalisme en zijn vooruitzichten', waar hij ervoor pleit om 'de doctrine, welke veelal het neoliberalisme wordt genoemd' ingang te doen vinden als 'een nieuw geloof'. Het begrip wordt op vergelijkbare neutrale of positieve wijze gebruikt door MPS-leden als Ludwig von Mises, Walter Eucken, Jacques Rueff, Ludwig Erhard, Albert Hunold, Müller-Armack, Röpke en Rüstow (Walpen, 2004, 48).

Belangrijk is dat er binnen dit netwerk vanaf het begin aanzienlijke onderlinge tegenstellingen bestonden. Het neoliberalisme was bij aanvang al een containerbegrip waarbinnen drie voornaamste stromingen kunnen worden onderscheiden: de Oostenrijkse School (onder anderen Mises, Machlup, Hayek), de Duitse ordoliberale school en/of Freiburger Schule (onder anderen Eucken, Röpke, MüllerArmack, Erhard, Rüstow), en de Amerikaanse Chicago School (onder anderen Friedman, Stiegler, Knight, Director). Deze stromingen verschilden van gedachten wat betreft de mate van overheidsingrijpen. Het ordoliberalisme legde meer nadruk op de noodzaak van een sterke staat om machtsconcentraties te voorkomen, en benadrukte de sociale en juridische randvoorwaarden voor het functioneren van de markt. De andere twee stromingen stonden principieel negatiever ten opzichte van overheidsingrijpen. Daarbij waren er ook verschillen in epistemologie. De Chicago School ging uit van een rationeel mensbeeld en was positivistisch, terwijl de andere twee stromingen sceptischer waren over het menselijk kenvermogen. Niettemin vonden de drie groepen elkaar in een negatieve positionering ten opzichte van laisser-faire enerzijds en het keynesianisme en centrale planning anderzijds.

Als grove werkdefinitie kunnen we stellen dat het neoliberalisme een politiek behelst die de samenleving zo ver mogelijk aan de hand van het marktmechanisme wenst te ordenen, waarbij de overheid de bestaansvoorwaarden voor de vrije markt moet waarborgen. De vrije markt ontstaat niet vanzelf en handhaaft zich niet vanzelf. De markt is maakbaar en de overheid dient het marktmechanisme actief te bevorderen en zo min mogelijk te corrigeren. Hayek noemde dit planning for competition (Hayek, 1944, 43). Over de vraag of daar een grote of juist 
een kleine overheid voor nodig is, en wat precies het domein van marktwerking en overheidsingrijpen is, bleven de meningen verschillen.

Desalniettemin werd de term neoliberalisme spaarzaam gebruikt door de leden van de MPS, omdat het van begin af aan een vechtbegrip was, onderwerp van discussie en controverse tussen de verschillende stromingen binnen de Mont Pèlerin Society. De term werd meer met de Duitse ordoliberalen geassocieerd, en de stromingen binnen de neoliberale beweging die tegen overheidsinterventie gekant waren, hadden er moeite mee. Hoewel de term later in onbruik zou raken en de leden van de MPS zich vandaag de dag eerder als klassiek-liberalen aanduiden, zijn onderzoekers het woord neoliberalisme blijven hanteren om de breuk te markeren die dit gedachtegoed vertegenwoordigt ten opzichte van het klassiekliberalisme.

Duizenden onderzoekers, politici, zakenlui en journalisten zouden de jaarlijkse bijeenkomsten van de MPS bijwonen, tot op de dag van vandaag. Directeurs van invloedrijke denktanks als de Amerikaanse Heritage Foundation en het Britse Institute of Economic Affairs (IEA) namen deel, om later de politiek van Reagan en Thatcher mede vorm te geven. Vanaf de jaren zestig en zeventig richtten de MPS-leden zich meer en meer op de ontwikkeling van een aantal specifieke velden in de economische wetenschap, waaronder monetarisme, public choice, supply-side economics en de human capital-theorie. MPS-leden als Friedrich Hayek, Milton Friedman, James Buchanan, George Stigler en Gary Becker wonnen in de jaren zeventig en tachtig de Nobel Memorial Prize en braken door in de economische wetenschap.

Toen het keynesianisme door de stagflatie van de jaren zeventig in een legitimiteitscrisis terechtkwam, hadden de neoliberalen hun antwoorden klaar. Toen Thatcher (in 1979) en Reagan (in 1981) aan de macht kwamen, wierpen zij zich op als pleitbezorgers van de ideeën van Hayek en Friedman. Vervolgens begon in 1982 de schuldencrisis in een reeks van ontwikkelingslanden, waarop het IMF en de Wereldbank internationaal een beleid van marktwerking begonnen voor te staan, bekend als de 'Washington Consensus'. Na de val van de Muur werd een vergelijkbare aanpak over Oost-Europa uitgerold (Ther, 2016). De Washington Consensus werd al snel gezien als toonbeeld van neoliberaal beleid. De receptuur bestond uit begrotingsdiscipline, belastingverlaging, liberalisatie van importheffingen en buitenlandse directe investeringen, privatisering van bedrijven in staatseigendom en ten slotte deregulering, ofwel de afschaffing van marktbeperkende regulering, in het bijzonder in de financiële sector.

De jaren negentig gelden als het ideologische hoogtij van het neoliberalisme. De oprichting van de Wereld Handelsorganisatie (WHO), de Europese interne markt en het Noord-Amerikaanse NAFTA-akkoord bestendigden het beleid van marktwerking en handelsliberalisering. Een reeks van auteurs wijzen daarbij op de ordoliberale oorsprong van de Europese interne markt en de Europese Monetaire Unie (Biebricher \& Vogelmann, 2017; Dardot \& Laval, 2014 Hien \& Joerges, 2017). De financiële crisis van 2008 werd aanvankelijk door Stiglitz en Klein beschreven als 'het Berlijnse Muur moment' van het neoliberalisme (Peck, 2010, 9). Het bezuinigingsbeleid dat in antwoord op de cisis werd geïmplementeerd, leidde echter weer tot reflecties over het opmerkelijke lijfsbehoud van dit gedachtegoed, zoals tot 
uiting komt in The strange non-death of neoliberalism van Colin Crouch (2011; cf. Blyth, 2013; Mirowski, 2013; Streeck, 2014).

\section{Naar een ideeëngerichte benadering van het Nederlandse neoliberalisme}

Binnen het onderzoek naar neoliberalisme kunnen grofweg drie benaderingen worden onderscheiden, elk met eigen sterke en zwakke punten. Er is de marxistische benadering van het neoliberalisme, waarvan David Harvey (2005) de belangrijkste vertegenwoordiger is. Volgens deze visie is het neoliberalisme bovenal een uitdrukking van klassenverhoudingen, meer in het bijzonder een revolte van de economische elite tegen de macht van arbeid in de jaren zeventig. In Nederland zijn politiek economen als Bastiaan van Apeldoorn, Nana de Graaff, Henk Overbeek en Angela Wigger (Van Apeldoorn e.a., 2009; Van Apeldoorn \& Overbeek, 2012) de belangrijkste exponenten van deze stroming. Daarnaast is er de foucauldiaanse analyse van het neoliberalisme als bestuurstechniek. Hierin ligt de nadruk op de rol van de staat in het reguleren van gedrag, en tevens op de vorming van het neoliberale subject als entrepreneur of the self. Deze benadering zien we bovenal terug in de sociologie, bestuurskunde en criminologie. In Nederland hebben auteurs als Marc Schuilenburg (2012), P.W. Zuidhof (2012a), Willem Schinkel en Friso van Houdt (2010; 2013) hiermee naam gemaakt. Een derde stroming kunnen we de ideeëngerichte benadering noemen, waaronder zowel meer klassiek ideeënhistorisch onderzoek valt (Audier, 2012; Burgin, 2012; Peck, 2010; Stedman, 2012; Walpen, 2004) als meer sociaalwetenschappelijke stromingen zoals institutionele analyse (Blyth, 2002; Hall, 1993; Hay, 2001). Binnen deze benadering ligt de nadruk minder op het neoliberalisme als een politiek-economisch en bestuurlijk model, en meer op het neoliberalisme als een politieke en intellectuele beweging, die op empirische wijze afgebakend en getraceerd kan worden aan de hand van archieven en primaire bronnen. Deze laatste benadering heeft natuurlijk ook zo haar tekortkomingen, maar is vanwege haar historiserende gerichtheid bijzonder geschikt om de huidige controverse rond het begrip neoliberalisme te ondervangen.

Onderscheidend aan de recente reeks van studies die zich richten op de ideeëngeschiedenis van het neoliberalisme (Audier, 2012; Burgin, 2012; Mirowski, 2013; Mirowski \& Plehwe, 2009; Peck, 2010) is dat zij kiezen voor een inductieve benadering waarbij het neoliberalisme niet gereduceerd wordt tot een abstracte, enkelvoudige essentie. Het gedachtegoed van de neoliberale beweging is enerzijds af te bakenen door haar historische positionering in de ideologische ruimte ten opzichte van klassiek-liberalisme en keynesianisme. Anderzijds kunnen de ideeën die circuleren in de netwerken van de MPS op vrij pragmatische wijze als bandbreedte aangehouden worden van het neoliberale gedachtegoed. Daarbij wordt ervan uitgegaan dat er geen pure vorm van neoliberalisme bestaat, en dat 'het neoliberalisme' geen eenduidige eindbestemming heeft. Het neoliberalisme treedt altijd in mengvormen op: het is gedoemd het podium te delen met (de overblijfselen van) andere politieke tradities - sociaaldemocratie, corporatisme, ontwikkelingseconomieën, centraal geplande sovjeteconomieën - en kent een verscheiden- 
heid aan nationale trajecten. Het is productiever, zo stellen onderzoekers, om deze verschillende parcoursen in hun onderlinge verbondenheid na te gaan dan deze te abstraheren tot een enkelvoudige essentie. Er zal daarbij een balans gevonden moeten worden tussen al te gestroomlijnde lezingen van het neoliberalisme (Bourdieu, 1998; Klein, 2007; Harvey, 2005) en interpretaties waarbij elke vorm van synthese wordt verworpen (Audier, 2012).

Uitgaande van de stelling dat er geen puur neoliberalisme is, enkel lokale en hybride varianten, rijst de vraag hoe we het Nederlandse neoliberalisme als politieke en intellectuele beweging kunnen herkennen en traceren. Allereerst is het mogelijk om op het niveau van concreet gedachtegoed dat in de netwerken rond de Mont Pèlerin Society is ontwikkeld, vergelijkbare denkpatronen in Nederland te zoeken, als in een vergelijkende literatuurstudie. Een tweede methode is om het neoliberalisme te reconstrueren aan de hand van de banden met internationale netwerken, en referenties aan auteurs en denktanks. Gebruikmakend van deze complementaire identificatiemechanismen kunnen we alvast de volgende bescheiden stappen zetten.

De opkomst van het neoliberalisme in Nederland kan grofweg opgedeeld worden in twee fasen. De eerste fase begon in 1934, toen Fentener van Vlissingen, medeoprichter van AkzoNobel en KLM, en F.H. en A.A. van Sandick van de Nederlandsche Handels Maatschappij gezamenlijk een lobbygroep van 'anti-devaluïsten' oprichtten. Dit politieke netwerk ging in 1938 op in het Comité ter Bestudering van Ordeningsvraagstukken. Na de Tweede Wereldoorlog groeide het in rap tempo uit tot spil in een omvangrijk netwerk van zelfbenoemde neoliberalen, met als centrale figuren de Hengelose industrieel Henri Keus en de rechtsgeleerde Josephus Jitta (Mellink, 2017, 2019). Het Comité ter Bestudering van Ordeningsvraagstukken (kortweg: Comité Ordeningsvraagstukken) legde contacten met internationaal gerenommeerde neoliberale denkers zoals Friedrich von Hayek, Wilhelm Röpke en Ludwig von Mises, en sloot zich in 1948 aan bij de zogenoemde Mont Pèlerin Society van Friedrich von Hayek, eerder in dit artikel beschreven als kraamkamer en zenuwcentrum van het internationale neoliberalisme (Mirowski \& Plehwe, 2009).

In Nederland verwierven de neoliberalen op drie manieren invloed. Allereerst voerde het Comité Ordeningsvraagstukken een gecoördineerde strategie om de publieke opinie in neoliberale richting te beïnvloeden. Daartoe vertaalde en verspreidde het Comité gedurende de jaren vijftig ongeveer vijftig vertaalde lezingen van leden van de Mont Pèlerin Society. De totale oplage van deze brochures was opvallend hoog - in zeven jaar werden 500.000 exemplaren verspreid -, maar nog opvallender was de gecoördineerde actie die daarachter schuilging: het Comité wilde, bij monde van het lid W.C. Mees, 'de studenten bewerken. Men zou in de bibliotheken een dossier moeten kunnen aanleggen. Daarvoor zou de Jouvenel [indertijd een Franse journalist met sterke neoliberale sympathieën] bijv. uiterst geschikt zijn. Daartoe moeten wij een laboratorium zijn' (Comité Ordeningsvraagstukken, 1948). Daarnaast werkte het Comité Ordeningsvraagstukken nauw samen met de Federatie Nederlandse Bedrijven en het daaruit voorgekomen Comité Burgerrecht, dat het neoliberale weekblad Burgerrecht uitgaf en dat door de leden van het Comité Ordeningsvraagstukken werd beschouwd als 'een bin- 
dend element en (...) - populair uitgedrukt - als de "stoottroep"' (Comité Ordeningsvraagstukken, 1947). Ook wisten de Nederlandse neoliberalen, mede dankzij de aanhoudende inspanningen van organisatietalent L.M. van Breen, voldoende kapitaal te verzamelen om Nederlandse dag- en weekbladtitels aan te kopen, waaronder De Nederlander, Het Kompas, De Prinsestad en in 1951 De Haagsche Post (Mellink, 2019). Van Breen hoopte aldus 'een ontspanningsblad in ten dele linkse kringen te brengen en daarin tevens te velde te trekken tegen de geleide economie, zonder dat de lezers weglopen' (Mellink, 2017). Die ambities slaagden maar ten dele: dankzij een slechte bedrijfsvoering ging het opgebouwde persimperium al in de jaren vijftig weer ter ziele, en moest De Haagsche Post worden verkocht.

Een tweede vorm van invloed vloeide voort uit de gedeelde ambitie van het Comité Ordeningsvraagstukken en het Comité Burgerrecht om geen eigen politieke partij op te richten, maar werkzaam te zijn als 'een stroming in het maatschappelijk leven, dus in de politieke partijen' (Comité Ordeningsvraagstukken, 1947). Burgerrecht-voorzitter J. van den Berge verdedigde deze koers door te stellen: 'indien de massa anders gaat denken, dan denken ook de politieke leiders weldra anders. Wij moeten werken naar het verkrijgen van een toestand en daartoe infiltrerend werk doen' (Mellink, 2017, 37). Binnen de politieke partijen zouden de neoliberalen weldra van zich laten horen. Binnen de Katholieke Volkspartij (KVP), destijds de grootste politieke partij van Nederland, voedden zij de rechtse oppositie, die ageerde tegen de roomsrode samenwerking van de KVP en de Partij van de Arbeid binnen de kabinetten-Drees. Door contacten te leggen met de conservatieve oud-minister van Koloniën Charles Welter hoopten de neoliberalen de onrust op de rechterflank van de katholieke zuil te voeden, terwijl zij tegelijkertijd probeerden om hun ideeën ook binnen de kleinere protestantse partijen, de AntiRevolutionaire Partij en de Christelijk-Historische Unie, onder de aandacht te brengen. Deze strategie wierp wel degelijk vruchten af. Binnen de christelijke partijen, in het bijzonder de KVP en de ARP, ontstonden interne conflicten over de uitbouw van de verzorgingsstaat. En daarbij werd de VVD voor zekere tijd gewonnen voor de neoliberale zaak: in een toespraak in 1952 observeerde partijleider P.J. Oud met vreugde 'dat er meer en meer waardering is voor het neoliberalisme dat wij voorstaan' (Oud, 1952; Oudenampsen, 2016). In tegenstelling echter tot West-Duitsland, waar de ordoliberalen aan de macht kwamen onder Ludwig Erhard van de CDU, wisten de Nederlandse neoliberalen de christelijke partijen niet volledig voor hun zaak te winnen (Mellink, 2017).

Een derde vorm van invloed betrof het naoorlogse industrialisatiebeleid. Onder druk van de neoliberale oppositie binnen haar partij stelde de KVP in 1948 een minister van Economische Zaken aan die een uitgesproken voorstander van marktgericht beleid was. Jan van den Brink had eerder dat jaar een ontmoeting met de Duitse econoom Ludwig Erhard, een van de oprichters van de Mont Pèlerin Society en de toekomstige Duitse minister van Economische Zaken. Hoewel Van den Brink het corporatistische Nederlandse industrialisatiebeleid onderscheidde van de 'individualistische' koers van Erhard, deelden zij een voorkeur voor een marktgerichte koers en een afkeer van keynesiaans beleid. Met hulp van het Burgerrecht-lid en Mont Pèlerin-lid H.I. Keus ontwikkelde Van den Brink een 
industrialisatiebeleid dat door lage lonen, deregulering en belastingverlaging het concurrentievermogen van de Nederlandse exportsector beoogde te bevorderen. Kenneth Dyson (2001) beschreef het naoorlogse Modell Deutschland als een complexe en antagonistische synthese van neoliberale en corporatistische elementen. Het was een dynamisch compromis tussen tegengestelde belangencoalities. In navolging van Dyson kunnen we stellen dat het Nederlandse naoorlogse beleid eveneens een gemengde orde was, een complexe synthese van neoliberale, corporatistische en ook sociaaldemocratische elementen (Oudenampsen \& Mellink, 2019). Door de nadruk binnen dit model op aanbodbeleid vormde Nederland in die jaren een uitzondering op het naoorlogse keynesiaanse 'compromis' dat internationaal in zwang was (en uitging van loongroei die gelijk opging met productiviteitsgroei). Pas met de loonexplosie van 1963 zou het keynesianisme echt doorbreken in Nederland en werd de verzorgingsstaat uitgebouwd. Dit 'keynesiaanse intermezzo' zou echter van relatief korte duur zijn.

Een tweede fase begint in het midden van de stagflatiecrisis in de jaren zeventig. De term 'neoliberalisme' was inmiddels minder aanwezig in het publieke debat, en er waren nog maar weinig neoliberalen te vinden die zich expliciet als zodanig identificeerden (Meijer, 1988; Boas \& Gans-More, 2009). De banden met het neoliberalisme van de jaren vijftig waren niettemin zichtbaar in de toonaangevende invloed van de economische ideeën die door MPS-leden als Friedrich Hayek, George Stigler, Milton Friedman, Gary Becker en James Buchanan zijn geformuleerd. De politieke doorbraak van het neoliberalisme werd voorafgegaan door de academische doorbraak van nieuwe economische theorieën, in het bijzonder monetarisme, nieuw-klassieke economie, public choice en supply-side economics. In Nederland vonden deze theorieën al snel weerklank onder beleidseconomen, over het algemeen opgeleid en politiek gevormd ten tijde van het sobere, marktgerichte beleid van de jaren vijftig. In het bijzonder de ministeries van Financiën en Economische Zaken waren vroege bolwerken van principiële oppositie tegen keynesiaans beleid. De topambtenaren op deze ministeries ontwikkelden zich al vroeg tot voortrekkers van een omslag richting een 'aanbodbeleid', dat als verzamelterm gold voor een marktgericht beleid dat expliciet geïnspireerd was op de bovengenoemde stromingen (Van Duyn, 1982; Van Sinderen \& Ravenstein, 1986; Lubbers, 1991; Oudenampsen \& Mellink, 2019). Al ten tijde van het kabinet-Den Uyl (1973-1977) ontstond er een hoogoplopend conflict tussen Den Uyl en zijn topambtenaren over het begrotingsbeleid. Zoals de monetarist Anton Knoester later zou stellen, werd gedurende het kabinet-Den Uyl al een mentale omslag gemaakt naar het marktgerichte aanboddenken (Knoester, 1989). 'Aanbodeconomen' bij de ministeries namen het initiatief en riepen in een reeks van rapporten en commissies op tot loonmatiging, marktwerking en inperking van de verzorgingsstaat (Griensven, 2009; Oudenampsen \& Mellink, 2019).

De politieke doorbraak volgde pas later, met het eerste kabinet-Lubbers (1982-1986). Met zijn driesporenbeleid zette Lubbers een fundamentele koerswijziging in, richting een neoliberaal aanbodbeleid (Knoester, 1989; Rutten, 1993; Oudenampsen, 2018). Het vormde het startsein van een beleid van loonmatiging, flexibilisering, belastingverlaging, heroverweging, privatisering, deregulering en decentralisatie. De nieuwe koers was volgens de verantwoordelijke topambtena- 
ren geïnspireerd op Reaganomics aan de ene kant en de eigen ervaringen uit de jaren vijftig met loonmatiging en marktgericht aanbodbeleid aan de andere (Oudenampsen \& Mellink 2019; Raes et al. 2002). De man die door velen gezien werd als het brein achter de hervormingen is de econoom Frans Rutten, de machtige secretaris-generaal van Economische Zaken (Albeda 1999; Jorritsma \& De Waard 2009; Kok 1987). Rutten publiceerde in 1987 een berucht nieuwjaarsartikel in economentijdschrift Economische Statistische Berichten (in Rutten, 1993). Hierin vatte hij de hervormingsagenda van de jaren tachtig samen onder de nogal depolitiserende noemer van 'De Nieuwe Zakelijkheid'. De kern van deze agenda was het terugdringen van de overheid tot haar primaire taken: 'De rijksoverheid dient zich te concentreren op primaire taken (zoals justitie, onderwijs, wegen, defensie) en dient de minder essentiële taken te beperken (allerlei subsidies en andere interventies in de markteconomie).' Rutten presenteerde deze agenda als onderdeel van een maatschappijvisie op lange termijn, die hij baseerde op het werk van Milton Friedman (Rutten, 1993, 55).

In tegenstelling tot de Verenigde Staten en Groot-Brittannië kende Nederland echter geen harde ideologische afrekening met de politieke orde van de jaren zeventig (Oudenampsen, 2018). Het CDA moest gedeeltelijk snijden in het eigen vlees en had electoraal niets te winnen bij een harde confrontatiepolitiek. De Nederlandse neoliberale omwenteling werd daarom gepresenteerd als een apolitieke en technocratische fix, met slogans als 'no-nonsense', 'het karwei klaren' en 'BV Nederland' - al gaf die laatste slogan wel enige richting aan. Zoals de politicoloog Hans Daalder achteraf vaststelde, had Lubbers' agenda van het terugdringen van de staat een duidelijk ideologisch karakter. Het was geïnspireerd op 'een neoliberaal, of zo men wil neo-conservatief, streven dat ook elders in de wereld ruim opgang deed' (Daalder, 1990, 250; zie ook Albeda, 1999). Tegelijkertijd merkte Daalder op dat Lubbers een terugkeer inluidde van de oude politieke traditie van 'het bewust depolitiseren van politieke keuzen'.

Dat wil niet zeggen dat er helemaal geen pogingen waren om het nieuwe marktgerichte beleid van een ideologisch fundament te voorzien. Bij het CDA was het bovenal de Rabobank topman Herman Wijffels, 'de filosoof achter Lubbers', die daartoe het initiatief nam via een reeks van rapporten van het Wetenschappelijk Instituut (CDA 1983; CDA 1984; CDA 1989). 'We hebben gezorgd voor een ideologische onderbouwing van het afbouwen van de verzorgingsstaat', zou Wijffels later claimen (Smit, 2014, 182). Die onderbouwing bestond uit een 'herijking van het christelijk-sociale gedachtegoed' en een nieuwe, marktgerichte interpretatie van sociaalchristelijke begrippen als gespreide verantwoordelijkheid, publieke gerechtigheid, subsidiariteit en soevereiniteit in eigen kring (Smit, 2014, 176-208). De uitbouw van de verzorgingsstaat had geleid tot een gebrek aan verantwoordelijkheidszin, zo luidde de analyse, en het terugdringen van de staatszorg zou de persoonlijke verantwoordelijkheidsbeleving kunnen herstellen (CDA, 1983). Het CDA noemde dit streven afwisselend 'de verantwoordelijke samenleving', 'de zorgzame samenleving' of 'de participatiesamenleving'. Het marktdenken binnen het CDA ging zo samen op met gemeenschapsdenken en kenmerkte zich door een strategie van 'responsibilisering', een centraal element in de fou- 
cauldiaanse analyse van het neoliberalisme (Lemke, 2002; Schinkel \& Van Houdt, 2010, Van Houdt \& Schinkel, 2013).

Ook binnen de VVD werden er pogingen ondernomen om het Nederlandse neoliberalisme verder uit te denken. Politici en intellectuelen zoals Frits Bolkestein, Karel Groenveld, Gerry van der List en Andreas Kinneging werkten hun neoliberale inspiraties - bovenal de ideeën van Friedrich Hayek - op grondige wijze uit in publicaties van de denktank van de VVD aan het einde van de jaren tachtig (Groenveld \& Kinneging, 1985; Groenveld, 1986; Kinneging, 1988; Bolkestein, 1995). Met name het pleidooi voor een 'waarborgstaat' zou een terugkerend motief blijven in het denken van de VVD. Deze ideologische herijking bleef binnen beide partijen echter controversieel en had opmerkelijk weinig impact op de publieke beeldvorming. De kabinetten-Lubbers zouden de geschiedenis ingaan als visieloos, anti-ideologisch en antipolitiek (NRC Handelsblad, 2018; De Rooy, 2005).

Waar de precieze contouren van het nieuwe paradigma in de jaren tachtig nog onduidelijk waren, ontstond in de jaren negentig geleidelijk een nieuwe marktgerichte consensus. Vanwege de oppositie van vakbonden en het vastlopen van het overleg werden in de jaren tachtig de sociale overlegstructuren nog grotendeels genegeerd (Knoester 1989; Becker 2001). Zoals Andrew Gambles (1988) beroemde beschrijving van thatcherisme in zijn boek The Free Economy and the Strong State nam de neoliberale omwenteling in Nederland aanvankelijk de vorm aan van een sterke staat die arbeid disciplineert om competitiviteit van het bedrijfsleven te herstellen. Consensus was in deze tijd nog ver te zoeken (Oudenampsen \& Mellink, 2019). Tot begin jaren negentig keerden aanbodeconomen en vooraanstaande politici zich nog tegen het poldermodel en laakten zij de 'stroperigheid' van het sociaal overleg (Becker, 2001; Hemerijck, 1998). Pas ten tijde van de paarse kabinetten, toen buitenlandse commentatoren lovend begonnen te schrijven over het Nederlandse model, werd het corporatisme omarmd als een logisch onderdeel van de nieuwe marktgerichte koers. Net als in de jaren vijftig kan het Nederlandse beleidsparadigma van de jaren negentig het beste worden beschreven als een ongelijksoortig geheel in plaats van een ideologische monoliet. Met andere woorden: het is een complexe en intern tegenstrijdige synthese van neoliberale, corporatistische en sociaaldemocratische elementen. In de internationale literatuur wordt ook wel gesproken over corporatistisch neoliberalisme en embedded neoliberalism, ofwel neoliberalisme met flankerend sociaal beleid (Ban, 2016; Blyth, 2002; Scholten, 1987; Van Apeldoorn e.a., 2009).

\section{Conclusie}

Het neoliberalisme is een vechtbegrip dat regelmatig onderwerp is van felle discussies op de landelijke opiniepagina's. De academische literatuur op dit terrein is nog opvallend onderontwikkeld. In dit artikel hebben we geprobeerd om de bestaande tegenstelling tussen voor- en tegenstanders van het begrip neoliberalisme te overstijgen door dieper in te gaan op de herkomst en betekenis van het begrip. Puttend uit een recente golf van internationale literatuur over het neoli- 
beralisme, hebben we een ideeëngerichte benadering van het neoliberalisme geïntroduceerd. Uitgangspunt van deze stroming is dat een universeel, puur neoliberalisme niet bestaat. Net als bij andere politieke stromingen, bestaat neoliberalisme uitsluitend in specifieke, lokaal ingebedde mengvormen. Het neoliberalisme in algemene zin is ten eerste af te bakenen via zijn verhouding ten opzichte van ideologische rivalen, in het bijzonder het klassiek-liberalisme en keynesiaanse planning. In de tweede plaats hebben specialisten een meer pragmatische, organisatorische identificatiemethode ontwikkeld, waarbij de netwerken van de Mont Pèlerin Society fungeren als ijkpunt en bandbreedte van het neoliberale gedachtegoed. Gebruikmakend van beide benaderingen hebben wij in vogelvlucht een indruk gegeven van de geschiedenis van het Nederlandse neoliberalisme.

Een voorlopige analyse op basis van dit vertrekpunt kan alvast een aantal misvattingen wegnemen. Ten eerste maakt het duidelijk dat het neoliberalisme een langere geschiedenis kent dan veelal wordt aangenomen. Die geschiedenis begint met de debatten over economische ordening in de jaren dertig. Ten tweede wordt duidelijk dat het neoliberalisme is ontstaan uit een trans-Atlantische dialoog, en niet te reduceren valt tot amerikanisering of het Angelsaksische model. Nederland heeft een eigenstandige traditie, die teruggaat tot de naoorlogse economische discussies over de inrichting van economie en samenleving. Ten derde blijkt dat het Nederlandse neoliberalisme niet gelijk kan worden gesteld met een immoreel individualisme, zoals vaak terugkomt in de populaire kritieken. In Nederland is de doorbraak van het marktdenken juist gelijk opgegaan met een sociaalchristelijke nadruk op verantwoordelijkheid en gemeenschapszin. Ten slotte komt naar voren dat het neoliberalisme geen afwezige overheid veronderstelt, integendeel: in de Nederlandse casus is de overheid juist een belangrijke initiatiefnemer van marktgerichte hervormingen.

Misschien is het goed om af te sluiten door kort nog iets te zeggen over de eigenheid van het Nederlandse neoliberalisme. Als we ervan uitgaan dat neoliberalisme altijd in mengvormen optreedt, is de meest logische benadering om niet een soort puur, abstract vrijemarktprincipe als ijkpunt te hanteren, maar eerder uit te gaan van een neoliberale omwerking van bestaande Nederlandse politieke tradities. Het Nederlandse politieke model is vaak in verband gebracht met depolitisering, corporatisme en technocratie (Daalder, 1974; Lijphart, 1968). Het is dan ook logisch om te verwachten dat neoliberale invloeden zich doen gelden op een relatief gedepolitiseerde, corporatistische en technocratische wijze. (Wat overigens niet betekent dat dit geheel zonder spanning en conflict is verlopen.) Het kernprobleem van deze benadering is dat het onbenoemd laat hoeveel gewicht precies aan neoliberalisme moet worden toegekend, en hoeveel aan de andere bepalende elementen van een dominant beleidsparadigma. Het loslaten van het idee van een puur neoliberalisme betekent immers ook dat er geen eenduidig referentiepunt bestaat dat ons toestaat vast te stellen hoe neoliberaal Nederland nu eigenlijk is. Daar zal toch een grove indicator voor moeten worden gevonden. Dit spanningsveld zal vast en zeker nog uitgebreider aan bod komen in ons onderzoek. Tot slot denken wij dat een ideeëngerichte benadering van het neoliberalisme een belangrijke bijdrage kan leveren aan historisch en sociaalwetenschappelijk onderzoek. Al 
is het alleen maar om de terechte kritiek dat de term zo vaak zonder onderbouwing wordt gebruikt eindelijk eens naar tevredenheid te kunnen beantwoorden.

\section{Literatuur}

Aalbers, M.B. (2016). Regulated deregulation. In: S. Springer, K. Birch \& J. MacLeavy (red.), Handbook of neoliberalism. Londen: Routledge, 563-574.

Achterhuis, H. (2010). De utopie van de vrije markt. Rotterdam: Lemniscaat.

Albeda, W. (1999). De droom van een humaan kapitalisme. Maandschrift Economie, 63: 406-426.

Ankersmit, F. (2009, 23 maart). Bolkestein moet zijn ouderwetse bril afdoen. De Volkskrant.

Apeldoorn, B. van, Drahokoupil, J., \& Horn, L. (2009). Contradictions and limits of neoliberal European governance. From Lisbon to Lisbon. Basingstoke: Palgrave.

Apeldoorn, B. van, \& Overbeek, H. (2012). Neoliberalism in crisis. Basingstoke: Palgrave.

Audier, S. (2012). Neoliberalisme(s). Une archeologie intellectuelle. Parijs: Bernard Grasset.

Ban, C. (2016). Ruling Ideas. How Global Neoliberalism Goes Local. New York: Oxford University Press.

Becker, U. (2001). Miracle by consensus? Consensualism and dominance in Dutch employment development. Economic and Industrial Democracy, 22 (4): 453-483.

Beus, J. de, Doorn, J. van, \& Rooy, P. de (1996). De ideologische driehoek. Nederlandse politiek in historisch perspectief. Amsterdam: Boom.

Biebricher, T., \& Vogelmann, F. (2017). The birth of austerity. German ordoliberalism and contemporary neoliberalism. Londen: Rowman \& Littlefield.

Blyth, M. (2002). Great transformations. Economic ideas and institutional change in the twentieth century . Cambridge: Cambridge University Press.

Blyth, M. (2013). Austerity. The history of a dangerous idea. Oxford: Oxford University Press.

Boas, T., \& Gans-Morse, J. (2009). Neoliberalism. From new liberal philosophy to anti-liberal slogan, Studies in Comparative International Developments, 44 (2): 137-161.

Bolkestein, F. (1995). Het heft in handen. Amsterdam: Prometheus.

Bolkestein, F. (2001). The EU's economic test. Meeting the challenges of the Lisbon strategy. Speech at the 17th Annual State of the International Economy Conference, organised by the Institute of Economic Affairs. Londen, 19 november. http://europa.eu/rapid/ press-release_SPEECH-01-546_en.htm?locale=en, geraadpleegd op 29 maart 2019.

Bolkestein, F. (2009, 17 maart). De ware liberaal is een realist. NRC Handelsblad .

Bourdieu, P. (1998). L'essence du néolibéralisme. Le Monde Diplomatique, maart.

Burgin, A. (2012). The great persuasion. Reinventing free markets since the depression. Cambridge, Mass.: Harvard University Press.

CDA (1983). Appel en weerklank: Van verzorgingsstaat naar verzorgingsmaatschappij. Den Haag: Wetenschappelijk Instituut voor het CDA.

CDA (1984). Werkloosheid en de crisis in onze samenleving. Den Haag: Wetenschappelijk Instituut voor het $\mathrm{CDA}$.

CDA (1989). Economische groei: Een christen-democratische beschouwing. Den Haag: Wetenschappelijk Instituut voor het CDA.

Centre for Policy Studies (1975). Why Britain needs a social market economy. Chichester: Barry Rose.

Comité Ordeningsvraagstukken (1947). Verslag bijeenkomst oprichting Landelijk Comité 14/11/47 (Heemaf Archief, inv. nr. 142). Hengelo: Historisch Centrum Overijssel. 
Comité Ordeningsvraagstukken (1948). Notulen vergadering 24/3/48 (Heemaf Archief, inv. nr. 1205). Hengelo: Historisch Centrum Overijssel.

Crouch, C. (2011). The strange non-death of neoliberalism. Cambridge: Polity Press.

Daalder, H. (1974). Politisering en lijdelijkheid in de Nederlandse politiek. Assen: Van Gorcum.

Daalder, H. (1990). Politiek en historie. Opstellen over Nederlandse politiek en Vergelijkende politieke wetenschap. Amsterdam: Bert Bakker.

Dardot, P., \& Laval, C. (2014). The new way of the world. On neoliberal society. Londen: Verso.

Duyn, J. van (1982). De economie van het aanbod. Pre-adviezen van de Vereniging voor de Staathuishoudkunde. Leiden: Stenfert Kroese.

Dyson, K. (2001). The German model revisited. From Schmidt to Schroder. German Politics, 10 (2): 135-154.

Friedman, M. (1952). Het neoliberalisme en zijn vooruitzichten. Den Haag: Comité voor Ordeningsvraagstukken.

Gamble, A. (1988). The Free economy and the Strong State. The politics of Thatcherism. Basingstoke: MacMillan.

Gray, J. (1993). Beyond the New Right. Markets, government and the common environment. Londen: Routledge.

Griensven, P. van (2009). De zure appel in tijden van economische crisis. In: C. van Balen e.a. (red.), Jaarboek Parlementaire Geschiedenis 2009 , 59-71.

Groenveld, K. (1986). Rawls en Hayek over liberale verdelingspolitiek. In: R. Vermunt \& H. Steensma (red.), Sociale rechtvaardigheid in een tijd van schaarste. Leiden: DWO Press, 39-48.

Groenveld, K., \& Kinneging, A. (1985). Liberalisme en politieke economie. Den Haag: Teldersstichting.

Haar, M. van de (2012, 15 februari). Het neoliberale fantoom. De Groene Amsterdammer .

Hall, P.A. (1993). Policy paradigms, social learning, and the state. The case of economic policymaking in Britain. Comparative Politics, 25 (3): 275-296.

Harvey, D. (2005). A brief history of neoliberalism. Oxford: Oxford University Press.

Hay, C. (2001). The 'crisis' of Keynesianism and the rise of neoliberalism in Britain, an ideational institutionalist approach. In: J. Campbell \& O. Pedersen (red.), The rise of neoliberalism and institutional analysis. Princeton: Princeton University Press, 193-218.

Hayek, F. (1944). The Road to Serfdom. Londen: Routledge.

Hayek, F. (1952). A rebirth of liberalism. The Freeman, 2: 729-731.

Hayek, F. (1967). Studies in philosophy, politics and economics. Londen: Routledge, 195-200.

Hees, M. van, Schie, P. van, \& Velde, M. van de (2014). Neoliberalisme. Een politieke fictie. Amsterdam: Boom.

Hemerijck, A.C. (1998). Het leervermogen van de overlegeconomie. In: F. Hendriks \& T. Toonen (red.), Schikken en plooien. De stroperige staat bij nader inzien., Assen: Van Gorcum, 117-134.

Hien, J., \& Joerges, C. (2017). Ordoliberalism, law and the rule of economics. Londen: Bloomsbury.

Houdt, F. van, \& Schinkel, W. (2013). A genealogy of neoliberal communitarianism. Theoretical Criminology, 17 (4): 493-516.

Jorritsma, E., \& Waard, M. de (2009, 5 januari). De SG is weer staatsdienaar, geen mooie zangvogel. NRC Handelsblad .

Kersbergen, K. van (1995). Social capitalism. A study of Christian Democracy and the welfare state. Londen: Routledge.

King, D.S. (1987). The New Right: Politics, markets and citizenship. Londen: Palgrave Macmillan. 
Kinneging, A. (1988). Liberalisme: een speurtocht naar de filosofische grondslagen. Den Haag: Teldersstichting.

Klein, N. (2007) The shock doctrine. The rise of disaster capitalism. New York: Picador.

Kok, W. (1987). Het bestuurlijke in de economie. Een kritiek op de nieuwe zakelijkheid. In: A. Knoester (red.), Lessen uit het verleden: 125 jaar Vereniging voor de Staathuishoudkunde. Leiden: Stenfert Kroese, 367-374.

Knoester, A. (1989). Economische politiek in Nederland. Leiden: Stenfert Kroese.

Lemke, T. (2002). Foucault, governmentality, and critique. Rethinking Marxism, 14 (3): 49-64.

Lijphart, A. (1968). The politics of accommodation. Pluralism and democracy in the Netherlands. Berkeley: California University Press.

Lubbers, R. (1991) Samen onderweg: Over democratie, christendom \& samenleving, economie en internationale vraagstukken. Utrecht: Het Spectrum.

Marijnissen, J. (2009). Tegenstemmen. Een antwoord op het neoliberalisme. Utrecht: Veen.

Meijer, G. (1988). Het neoliberalisme. Neoliberalen over economische orde en economische theorie. Assen: Van Gorcum.

Mellink, B. (2017). Politici zonder partij. Sociale zekerheid en de geboorte van het neoliberalisme in Nederland (1945-1958). BMGN - The Low Countries Historical Review, 132 (4): 25-52.

Mellink, B., \& Zuidhof, P.W. (2018). Market government. Neoliberalism and the transformative power of 1989. In: E. Braat \& P. Corduwener (red.), 1989 and the West. Western Europe since the end of the Cold War. Londen: Routledge, forthcoming.

Mirowski, P. (2013). Never let a serious crisis go to waste. How neoliberalism survived the financial meltdown. New York: Verso Books.

Mirowski, P., \& Plehwe, P. (2009). The road from Mont Pèlerin. The making of the neoliberal thought collective. Cambridge, Mass.: Harvard University Press.

Nash, G. (2006 [1976]). The conservative intellectual movement in America since 1945. Wilmington: ISI Books.

NRC Handelsblad (2018, 17 februari). Politiek betaalde de prijs voor Lubbers' no nonsense beleid. NRC Handelsblad.

Oenen, G. van (2009). oudeVrijstaat. Hoe Amsterdam in 1980 zijn onschuld verloor. De Witte Raaf, 24 (141).

Oud, P.J. (1952, 3 mei). Socialistische vrijheid is gelijk aan die van het onmondige kind in de hoede van een welmenende vader. Vrijheid en Democratie.

Oudenampsen, M. (2016). A dialectic of freedom. The Dutch post-war clash between socialism and neoliberalism. Socialism and Democracy, 30: 128-148.

Oudenampsen, M. (2018). The conservative embrace of progressive values. On the intellectual origins of the swing to the right in Dutch politics (dissertatie Tilburg University).

Oudenampsen, M., \& Mellink, B. (2019). Bureaucrats first. The leading role of policymakers in the Dutch economic paradigm-shift of the 1980s. TSEG, forthcoming.

Paus Johannes Paulus II (1999). Ecclesia in America. Report of the Synod of America, 56.

Peck, J. (2010). Constructions of neoliberal reason. Oxford: Oxford University Press.

Raes, S., Sinderen, J. van, Winden, P. van, \& Biessen, G. (2002). Het maken van economisch beleid. De rol van AEP in de afgelopen 50 jaar. Tijdschrift voor politieke economie, 24: 7-50.

Rooy, P. de (2005). Republiek van rivaliteiten. Nederland sinds 1813. Amsterdam: Mets \& Schilt.

Rossem, M. van (2011). Kapitalisme zonder remmen. Opkomst en ondergang van het marktfundamentalisme. Amsterdam: Nieuw Amsterdam. 
Rutten, F.W. (1993). Zeven kabinetten wijzer. De nieuwe zakelijkheid bij het economische beleid. Groningen: Wolters Noordhoff.

Rutten, F.W. (1995). Verval, herstel en groei. Lessen voor het economisch beleid gelet op het leergeld van twintig jaar. Utrecht: Lemma.

Sanders, S. (2009, 27 april). Het individualisme onderscheidt de liberalen van Wilders. NRC Handelsblad .

Schinkel, W., \& Houdt, F. van (2010). The double helix of cultural assimilationism and neoliberalism: citizenship in contemporary governmentality. The British Journal of Sociology, 61 (4): 696-715.

Scholten, I. (1987). Corporatism and the neo-liberal backlash in the Netherlands. In: I. Scholten (red.), Political stability and neo-corporatism. Corporatist integration and societal cleavages in Western Europe. Londen: Sage.

Schuilenburg, M. (2012). Orde in veiligheid. Een dynamisch perspectief. Den Haag: Boom Lemma.

Sinderen, J. van, \& Ravenstein, A. (1986). New classicals en supply-siders: Een overzicht van hun ideeën en beleidsaanbevelingen. Den Haag: AEP.

Slobodian, Q. (2018). Globalists. The end of empire and the birth of neoliberalism. Cambridge (Mass.): Harvard University Press.

Smit, J. (2014). De opdracht. Of de vele gezichten van Herman Wijffels. Amsterdam: Balans.

Stedman J.D. (2012). Masters of the universe. Hayek, Friedman and the birth of neoliberal politics. New Jersey: Princeton University Press.

Streeck, W. (2014). Buying time. The delayed crisis of democratic capitalism. Londen: Verso.

Swaan, B. de (2010) Het financieel regime. Over de gevolgen van een moderne dwaalleer. Thomas More Lezing, 17 november 2010 Online beschikbaar op: http://www.mejudice. $\mathrm{nl} /$ artikelen/detail/het-financieel-regime-over-de-gevolgen-van-een-modernedwaalleer

Ther, P. (2016). Europe since 1989. A history. New Jersey: Princeton University Press.

Tromp, J. (2010) Het kaartenhuis. Hoe de bonus bloeit en de rest verdort. Amsterdam: Balans.

Touwen, J. (2014). Coordination in transition. The Netherlands and the world economy, 1950-2010. Leiden: Brill.

Voerman, G. (2011). De conjunctuur van de macht. Het Christen Democratisch Appèl 1980-2010. Amsterdam: Boom.

Walpen, B. (2004). Der Plan, das Planen zu beenden (dissertatie University of Amsterdam).

Wöltgens, T. (1996). De nee-zeggers, of de politieke gevolgen van het economisch liberalisme. Amsterdam: Prometheus.

Zuidhof, P.W. (2012a). Imagining markets: The discursive politics of neoliberalism. Dissertation, Erasmus University Rotterdam.

Zuidhof, P.W. (2012b). Ayn Rand: Fountainhead of Neoliberalism? Krisis 2012 (1): 84-89. 